\title{
COMMON BEANS GENOTYPES BEHAVIOR CULTIVATED IN CERRADO SOILS OF SOUTHERN TOCANTINS
}

\author{
COMPORTAMENTO DE GENÓTIPOS DE FEIJÃO COMUM CULTIVADOS EM \\ SOLOS DE CERRADO NO SUL DO TOCANTINS
}

\begin{abstract}
Rodrigo Ribeiro FIDELIS ${ }^{1}$; Sérgio Alves de SOUSA² ${ }^{2}$ Roberto Antonio Savelli MARTINEZ ${ }^{3}$; Taynar Coelho de OLIVEIRA ${ }^{4}$; Danilo Pereira RAMOS ${ }^{5}$; Leila Paula TONELLO ${ }^{6}$

1. Professor, Doutor, Programa de Pós Graduação em Produção Vegetal, universidade Federal do Tocantins - UFT, Gurupi, TO, Brasil; 2. Doutorando em Produção Vegetal - UFT, Gurupi, TO, Brasil; 3. Professor, Doutor, Universidade do Estado de Mato Grosso, Tangará da Serra, MT, Brasil; 4. Engenheira Agrônoma, Pesquisadora PNPD, UFT, Gurupi, TO, Brasil; 5. Engenheiro Agrônomo, UFT, Gurupi, TO, Brasil; 6. Engenheira Agrônoma, Mestre em Produção Vegetal - UFT, Gurupi, TO, Brasil.
\end{abstract}

\begin{abstract}
Common bean was originated from the Americas and has shown enormous socioeconomic importance as the main source of feeding in many countries. Due to adoption of technologies such as irrigation, the bean has been cultivated at different times throughout the year, however, the lack of cultivars adapted to the climatic conditions of the Cerrado of Tocantins has limited obtaining best yields at the time of the season. Thus, the aim of this work was to evaluate the performance of common bean genotypes in three cropping years in Cerrado soils. The experiments were conducted in the field at the Experimental Station of the Federal University of Tocantins in the dry season of the years 2010, 2011 and 2012. The experimental design was a randomized block with four replications in a 8 x 3 factorial, consisting of eight genotypes and three years. The evaluated characteristics were plant height, the first pod height, number of pods per plant, number of seeds per pod, weight of hundred grains and grain yield. The Princesa genotype stood out with yields above $3,000 \mathrm{~kg} \mathrm{ha}^{-1}$ in more than a year of cultivation, demonstrating its potential for cropping systems in the State of Tocantins. The genotype BRS-Esplendor was the only genotype that showed stable behavior for all traits.
\end{abstract}

KEYWORDS: Phaseolus vulgaris. Offseason cropping. Productivity. Food security.

\section{INTRODUCTION}

Common bean (Phaseolus vulgaris L.) is a native species of the Americas (FREITAS, 2006), that besides the economic importance has a social one as a food rich in protein and energy and as a generating source of jobs due to high demand for labor (SANTI et al., 2006).

Brazil is among the world largest beans producers, where national production estimates considering the three cropping periods for the cropping years of 2012/2013 is approximately 3.3 million tons in an area of 3.2 million hectares and an average yield of $1,050 \mathrm{~kg} \mathrm{ha}^{-1}$. As for the State of Tocantins production estimates are approximately of 49,800 tons with an verage yield of $1,510 \mathrm{~kg} \mathrm{ha}^{-1}$, on an area of 33 thousand hectares (CONAB, 2013).

With technologies adoption such as irrigation, allowed common beans cultivation on three different seasons throughout the year, however, not always, yields are considered satisfactory at all times due to various factors, including climate and adoption of cultivars not adapted to cultivation locations (LOPES et al., 2011; ZUCARELI et al., 2006; ZUCARELI et al., 2011).

In the State of Tocantins, the offseason cultivation has excelled and demonstrated enormous potential, representing approximately $56 \%$ of total grain production in the state and an expected average productivity of $1,850 \mathrm{~kg} \mathrm{ha}^{-1}$ for the season 2012/2013 (CONAB, 2013). That potential has been confirmed by studies on those growing seasons in the southern state of Tocantins, with productivities exceeding $3000 \mathrm{~kg} \mathrm{ha}^{-1}$ (SALGADO et al., 2011). Another factor that enhances the cultivation of this crop in Tocantins is its strategic geographic location, situated in an exporting corridor to several other regions of the country (PIRES et al., 2012).

Besides other factors, the one, which have limited achieving satisfactory productivities with the cultivation of common beans in the Tocantins cerrado soils at the offseason period, is the lack of use of improved cultivars that are specifically for these edaphic-climatic conditions. Given the consume demand and consequently the need for increases in productivity, the research on breeding have intensified, looking for bean genotypes that are highly productive and adapted to different environment conditions (FARINELLI; LEMOS, 2010; RAMOS JUNIOR et al., 2005). Many other studies were developed in regards to this issue in terms of Tocantins cerrado with crops such as maize (CANCELLIER et al., 2011a; CANCELLIER et al., 2012) and soybeans (PELUZIO et al., 2008; PELUZIO et al., 2010; PIRES et al., 2012). 
However, studies with the common bean crop at the offseason cropping in the cerrado conditions of the state of Tocantins are scarce, being needed more research on that regard. Pereira et al. (2009) reaffirm the importance of those studies for understanding the cultivars adaptation and stability to different environments and years of cultivation.

Given this context, the aim of this work was to evaluate the performance of common bean genotypes in three offseason cultivations in cerrado soil of the southern state of Tocantins.

\section{MATERIAL AND METHODS}

The experiments were conducted in the offseason on the years of 2010, 2011 and 2012 at the experimental station of the University of Tocantins, in the University Campus of the municipality of Gurupi, located at latitude $11^{\circ} 43^{\circ}$ $45^{\prime \prime} \mathrm{S}$ and a longitude of $49^{\circ} 04^{\prime} 07^{\prime} \mathrm{W}$, at $280 \mathrm{~m}$ altitude. According to Embrapa (2006), the soil is classified as Typic Yellow-Red Dystrophic Latosol, with $735.2,57.2$ and $207.6 \mathrm{~g} \mathrm{~kg}^{-1}$ sand, silt and clay, respectively. The climatic data for the conduction period of the experiments are shown in Figure 1.

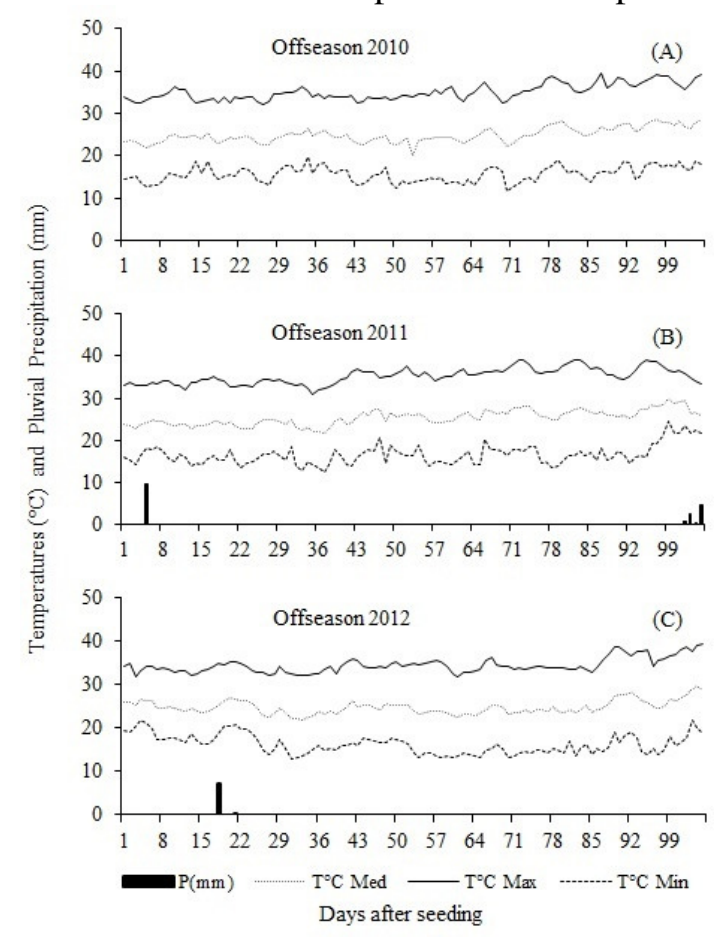

Figure 1 Pluvial precipitation $(\mathrm{mm})$ and maximum, medium and minimum temperatures $\left({ }^{\circ} \mathrm{C}\right)$ occurred during cultivation of common bean genotypes in the offseason of (A) 2010, (B) 2011 and (C) 2012 (BDMEP 2012).

In the area where the experiments were carried out, there is a history of use in crop rotation with rice cultivation in the cropping season and common bean in the offseason. In 2009, liming was performed for correcting soil acidity. Previous installation of experiments, at each year soil samples from the $0-20 \mathrm{~cm}$ layer were collected to characterize the chemical and physical properties, which are presented in Table 1.

The genotypes evaluations were conducted in experiments with experimental design in randomized blocks with four replications in a factorial scheme $3 \times 8$, made up of eight genotypes and three years. Each experimental unit consisted of four rows of $4.0 \mathrm{~m}$ long, spaced $0.45 \mathrm{~m}$. As a useful area, the two central lines were used disregarding $0.50 \mathrm{~m}$ from the ends of each line and eliminating the two sidelines, cropping up rows of $3.0 \mathrm{~m}$ long, a useful area of $2.7 \mathrm{~m}^{2}$.

To perform the studies seven cultivars (BRS-Esplendor, IAC-Diplomata, IAC-Una, IACCentauro, IPR-Colibri, Safira and Princesa) and a lineage (CNFC-10406) were used in the three evaluation years. In all years, the tillage was performed conventionally, with plowing and two disking. Sowing were held on June 12, 2010, June 21, 2011 and June 2, 2012, in order to obtain final stand of 12 plants per linear meter. 
Table 1. Soil depth 0-20 cm Chemical and physical properties in the experiment areas.

\begin{tabular}{|c|c|c|c|}
\hline \multirow{2}{*}{ Soil attributes } & \multicolumn{3}{|c|}{ Offseason } \\
\hline & 2010 & 2011 & 2012 \\
\hline $\mathrm{Ca}\left(\mathrm{cmol}_{\mathrm{c}} \mathrm{dm}^{-3}\right)$ & 3.60 & 1.00 & 0.80 \\
\hline $\mathrm{Mg}\left(\mathrm{cmol}_{\mathrm{c}} \mathrm{dm}^{-3}\right)$ & 1.40 & 0.60 & 0.60 \\
\hline $\mathrm{K}\left(\mathrm{cmol}_{\mathrm{c}} \mathrm{dm}^{-3}\right)$ & 0.10 & 0.10 & 0.08 \\
\hline $\mathrm{Al}\left(\mathrm{cmol}_{\mathrm{c}} \mathrm{dm}^{-3}\right)$ & 0.00 & 0.00 & 0.00 \\
\hline $\mathrm{H}+\mathrm{Al}\left(\mathrm{cmol}_{\mathrm{c}} \mathrm{dm}^{-3}\right)$ & 4.70 & 1.30 & 0.23 \\
\hline $\mathrm{pH}\left(\mathrm{CaCl}_{2}\right)$ & 4.60 & 4.50 & 5.30 \\
\hline P-melich $\left(\mathrm{mg} \mathrm{dm}^{-3}\right)$ & 1.10 & 15.60 & 9.90 \\
\hline $\mathrm{T}\left(\mathrm{cmol}_{\mathrm{c}} \mathrm{dm}^{-3}\right)$ & 9.80 & 3.00 & 1,70 \\
\hline $\mathrm{V}(\%)$ & 52.00 & 56.60 & 88,20 \\
\hline O.M $(\%)$ & 2.00 & 1.50 & 1.10 \\
\hline
\end{tabular}

The sowing fertilization was performed at the planting furrow based on the results of soil analysis of each year and recommendations for the common bean crop. There were applied $120.7 \mathrm{~kg}$ ha 1 of $\mathrm{P}_{2} \mathrm{O}_{5}$ and $21.3 \mathrm{~kg} \mathrm{ha}^{-1}$ of $\mathrm{N}$ as single superphosphate ammoniated (03-17-00 NPK formulation) in 2010, and amount of $50 \mathrm{~kg} \mathrm{ha}^{-1}$ of $\mathrm{K}_{2} \mathrm{O}$ as potassium chloride. In the year of 2011, $113.9 \mathrm{~kg} \mathrm{ha}^{-1}$ of $\mathrm{P}_{2} \mathrm{O}_{5}$ and $20.1 \mathrm{~kg} \mathrm{ha}^{-1}$ of $\mathrm{N}$ as ammoniated superphosphate, and $60 \mathrm{~kg} \mathrm{ha}^{-1} \mathrm{de} \mathrm{K}_{2} \mathrm{O}$ as potassium chloride, and in 2012, $114.92 \mathrm{~kg} \mathrm{ha}^{-1}$ of $\mathrm{P}_{2} \mathrm{O}_{5}$ and $20.28 \mathrm{~kg} \mathrm{ha}^{-1}$ of $\mathrm{N}$ as ammoniated superphosphate, and $60 \mathrm{~kg} \mathrm{ha}^{-1}$ de $\mathrm{K}_{2} \mathrm{O}$ in the form of potassium chloride.

Each year, topdressing was performed by applying $100 \mathrm{~kg} \mathrm{ha}^{-1}$ of $\mathrm{N}$ in two installments, in each coverage-applied a dose of $50 \mathrm{~kg} \mathrm{ha}^{-1}$ of N. In 2010, $50 \mathrm{~kg} \mathrm{ha}^{-1} \mathrm{~N}$ was applied as urea at 15 and 30 days after seedling emergence (DAE). In 2011, similar procedure was carried out, however, deferring the source used which was ammonium sulphate. In the 2012 offseason, the installment was performed with a cover at 20 DAE using ammonium sulfate as a source and another coverage at 30 DAE, being used urea as the source.

In all cultivation years, the water provided for irrigation was supplied by means of a conventional spray system in an irrigation interval of two days with operation periods of two hours applying $5.2 \mathrm{~mm} /$ hour. The water supply was made so that culture should not suffer from water stress at critical stages (LEMOS et al., 2004).

The phytosanitary treatments were carried out according to the needs and recommendations for the crop. In the years of 2011 and 2012, the same dose of the herbicide belonging to the chemical group benzothiadiazinone was applied. However, due to high weed infestation in the year 2012, the application had to be made about three days before the technical recommendation (V3) at the end of the phenological phase V2, when the first trifoliate was in the early development stages and not fully developed, resulting in plants Phytotoxycity.

To evaluate the phytotechnical characteristics, sampled of five random plants in each plot were taken. The evaluated characteristics were Plant height - by measuring the plant from the base of the stem to the end of the main stem. Insertion height of first pod - by measuring from the ground to the point of insertion of the first pod. Number of pods per plant - being obtained by counting the total number of pods per plant. Number of seeds per pod - obtained by the total number of grains and dividing the result by the total number of pods. Weight of hundred grains - taking up a hundred grains of the useful area, and weighing and correcting the humidity to $13 \%$. In addition, grain yield - done by grain weight in kilograms of the useful area, corrected to $13 \%$ moisture transforming the data to $\mathrm{kg} \mathrm{ha}^{-1}$.

The experimental data were subjected to individual and combined analysis of variance, applying the $\mathrm{F}$ test. The combined analysis was performed under conditions of homogeneity of residual variances. The tests used to compare the means were the grouping of Scott - Knott to assess the effects of treatments (genotypes) and Tukey for environments (off-season's 2010, 2011 and 2012), at $5 \%$ probability, and used the computational application SISVAR (FERREIRA, 2011). The Pearson correlation at $\mathrm{p}<0.05$ was also performed.

\section{RESULTS AND DISCUSSION}

For all evaluated traits, there was significance for genotype versus environment interaction, which features interdependence of factors, meaning that, environments (years) differentially influenced the expression of genotypes. Thus, there was a split of a factor inside the other. Similar results were obtained by (FARINELLI; LEMOS, 2010), which assessing the productive performance of 24 genotypes in 
different growing seasons also observed significance for the interaction of genotypes versus environment for all traits .

There was also significance for all traits studied in the factor genotype, evidencing the genetic variability existing among them. This information is crucial for selection of better-adapted cultivars to offseason conditions in the Cerrado in the south of Tocantins, as well as for future breeding programs with common bean crops (CABRAL et al., 2011; CANCELLIER et al., 2011b; MELO et al., 2007;). For the environment factor there was significance for all traits, evidencing differences between years for the conditions of soil and climate variations.

The variation coefficients observed are considered adequate according to Oliveira et al. (2009), which is indicative of good experimental precision.

In Table 2 are presented the average height of plants for three growing seasons. For the year 2010 , the group with a greater height was composed by a single genotype (Princesa with $85.10 \mathrm{~cm}$ ). The smaller heights were obtained by the group composed of the genotypes BRS-Esplendor, IPRColibri, IAC-Una and CNFC-10406, ranging from 54.30 to $64.82 \mathrm{~cm}$.

Table 2. Plant height means of eight common bean genotypes grown in the southern state of Tocantins, in the offseasons of 2010, 2011 and 2012.

\begin{tabular}{lcccc}
\hline \multirow{2}{*}{ Genotypes } & \multicolumn{4}{c}{ Plant height $(\mathrm{cm})$} \\
\cline { 2 - 5 } & offseason 2010 & offseason 2011 & offseason 2012 & Means \\
\hline IAC-Una & $54.30 \mathrm{cB}$ & $73.20 \mathrm{cA}$ & $66.32 \mathrm{bAB}$ & 64.60 \\
IAC-Centauro & $71.62 \mathrm{bA}$ & $67.80 \mathrm{dA}$ & $53.60 \mathrm{cB}$ & 64.34 \\
Princesa & $85.10 \mathrm{aA}$ & $87.86 \mathrm{bA}$ & $83.95 \mathrm{aA}$ & 85.63 \\
CNFC-10406 & $64.82 \mathrm{cA}$ & $76.86 \mathrm{cA}$ & $75.80 \mathrm{aA}$ & 72.49 \\
IPR-Colibri & $56.80 \mathrm{cAB}$ & $61.80 \mathrm{dA}$ & $48.07 \mathrm{cB}$ & 55.55 \\
IAC-Diplomata & $72.60 \mathrm{bB}$ & $100.60 \mathrm{aA}$ & $57.20 \mathrm{bC}$ & 76.80 \\
Safira & $69.77 \mathrm{bA}$ & $81.13 \mathrm{cA}$ & $76.12 \mathrm{aA}$ & 75.67 \\
BRS-Esplendor & $59.70 \mathrm{cA}$ & $69.26 \mathrm{dA}$ & $60.20 \mathrm{bA}$ & 63.05 \\
\hline Means & 66.84 & 77.31 & 65.15 &
\end{tabular}

Means followed by the same lower case letter in the column do not differ by the Scott - Knott test and a capitalized letter in the line by the Tukey test, both at $5 \%$ probability $. \mathrm{VC}=11.03 \%$ and $\mathrm{F}$ test $=4.597 * *$

In 2011, the only genotype to join the taller group was IAC - Diplomata with $100.60 \mathrm{~cm}$ (Table 2). The genotypes BRS-Esplendor, IPR-Colibri and IAC-Centauro composed the group of the smallest heights with means equal or lesser than $69.26 \mathrm{~cm}$. The Princesa genotype although did not made part of the group of higher stature, as in 2010, stood out composing the second group of the greater heights in 2011. In 2012, Princesa genotype again joined the group with greater height along with Safira and CNFC-10406, with means equal or greater than $75.80 \mathrm{~cm}$ (Table 2). Just as in 2012, the IACCentauro integrated the group of smaller heights of plants.

The IAC-Diplomata genotype was the only one to show a significant difference between each year of cultivation, demonstrating instability in the obtained heights, since that for 2010 to 2011 there was an increase of $39 \%$ in height and from 2011 to 2012, there was a decrease of $43 \%$. In the other hand the Princesa stood out obtaining the highest means in the years of 2010 and 2012 and the second highest average in 2011, although not statistically different between years was present. This genotype behaved stably for this feature, with minimal variation observed between years. The CNFC10406, Safira and BRS-Esplendor genotypes also showed a tendency to be stable for this trait.

The values found for plant height ranged from 48.07 to $100.60 \mathrm{~cm}$ (Table 2). It is observed that except for genotype IPR-Colibri in 2012 that showed the height of $48.07 \mathrm{~cm}$, all other genotypes heights over $50 \mathrm{~cm}$. Santi et al. (2006) also observed mean heights greater than $50.0 \mathrm{~cm}$ in evaluations of planting periods and installments of nitrogen fertilization on bean plants. In the same way Salgado et al. (2011) at lower dose $\left(80 \mathrm{~kg} \mathrm{ha}^{-1} \mathrm{~N}\right)$, obtained height of plants above $50.0 \mathrm{~cm}$.

For the characteristic height of insertion of the first pod (Table 3), it was observed that in 2010 the genotypes were classified into two statistical groups, with the highest averages composed of three genotypes (IAC-Diplomata, Princesa and BRSEsplendor), with the heights of insertion of the first pod exceeding $24.52 \mathrm{~cm}$. For the second group consisting of five genotypes (CNFC-10406, Safira, IAC-Una, IAC-Centauro e IPR-Colibri) the averages were lower than $21.92 \mathrm{~cm}$. 
In 2011, the genotypes were classified into three groups, with the greatest heights of insertion of the first pod consisting of three genotypes (IACCentauro, Princesa and IAC-Diplomata) with values ranging from 23.26 to $25.60 \mathrm{~cm}$. In the year 2012, all genotypes showed similar behavior for the height of first pod characteristic.

Table 3. Height of first pod insertion means of eight genotypes of common bean grown in the southern state of Tocantins, in the offseason of 2010, 2011 and 2012.

\begin{tabular}{lcccc}
\hline \multirow{2}{*}{ Genotypes } & \multicolumn{4}{c}{ Height of first pod insertion $(\mathrm{cm})$} \\
\cline { 2 - 5 } & Offseason 2010 & Offseason 2011 & Offseason 2012 & Means \\
\hline IAC-Una & $21.52 \mathrm{bA}$ & $18.13 \mathrm{cA}$ & $19.50 \mathrm{aA}$ & 19.71 \\
IAC-Centauro & $20.95 \mathrm{bA}$ & $23.26 \mathrm{aA}$ & $20.47 \mathrm{aA}$ & 21.56 \\
Princesa & $24.65 \mathrm{aAB}$ & $25.60 \mathrm{aA}$ & $21.20 \mathrm{aB}$ & 23.81 \\
CNFC-10406 & $21.92 \mathrm{bA}$ & $22.53 \mathrm{bA}$ & $20.50 \mathrm{aA}$ & 21.65 \\
IPR-Colibri & $19.80 \mathrm{bAB}$ & $22.30 \mathrm{bA}$ & $17.72 \mathrm{aB}$ & 19.94 \\
IAC-Diplomata & $25.72 \mathrm{aA}$ & $25.40 \mathrm{aA}$ & $20.93 \mathrm{aB}$ & 24.01 \\
Safira & $21.55 \mathrm{bA}$ & $21.40 \mathrm{bA}$ & $22.52 \mathrm{aA}$ & 21.82 \\
BRS-Esplendor & $24.52 \mathrm{aA}$ & $21.00 \mathrm{bA}$ & $22.47 \mathrm{aA}$ & 22.66 \\
\hline Means & 22.58 & 22.45 & 20.66 & \\
\hline
\end{tabular}

Means followed by the same lower case letter in the column do not differ by the Scott - Knott test and with a capitalized letter on the line by Tukey test, both at $5 \%$ probability. $\mathrm{VC}=10.33 \%$ and $\mathrm{F}$ test $=2.048 *$

The Princesa, IPR-Colibri and IACDiplomata genotypes were the only ones to show a significant difference between years, and the crops in the years 2010 and 2011 obtained the greatest heights of insertion of the first pod, with no statistical difference between them. Smaller heights of first pod insertion observed in the year 2012 for genotypes that showed significant differences between years are a reflection of the positive correlation $\left(\mathrm{r}=0.48^{* *}\right)$ existing between the plant height and height of first insertion pod, thus the genotypes with the lowest plant heights tended to have lower heights insertion of the first pod. Again, the genotype Princesa stood out integrating the group of higher values in three years, thus also confirming the existing correlation.
The evaluated genotypes showed insertion height of the first pod superior to $17.0 \mathrm{~cm}$ in all years (Table 3 ). These results agree with the values found in studies evaluating the effects of nitrogen fertilization on bean by Santi et al. (2006) who obtained average height of insertion of the first pod above 24.36. This result is of vital practical importance when one considers the embodiment of mechanized harvesting, since these larger heights reduce crop losses and the incidence of fungal disease originated from the soil.

For the characteristic number of pods per plant (Table 4), in 2010 the formation of a single statistical group was observed, demonstrating a similar behavior between genotypes, ranging from 9.86 to 14.77 pods per plant (Table 4).

Table 4. Number of pods per plant means of eight common bean genotypes grown in the southern state of Tocantins, in the offseason of 2010, 2011 and 2012.

\begin{tabular}{lcccc}
\hline \multirow{2}{*}{ Genotypes } & \multicolumn{4}{c}{ Number of pods per plant } \\
\cline { 2 - 5 } & Offseason 2010 & Offseason 2011 & Offseason 2012 & Mean \\
\hline IAC-Una & $13.73 \mathrm{aA}$ & $14.00 \mathrm{aA}$ & $12.07 \mathrm{aA}$ & 13.26 \\
IAC-Centauro & $14.25 \mathrm{aA}$ & $8.60 \mathrm{bB}$ & $6.47 \mathrm{bB}$ & 9.77 \\
Princesa & $14.77 \mathrm{aA}$ & $11.53 \mathrm{bAB}$ & $10.90 \mathrm{aB}$ & 12.40 \\
CNFC-10406 & $9.86 \mathrm{aB}$ & $15.00 \mathrm{aA}$ & $10.40 \mathrm{aB}$ & 11.75 \\
IPR-Colibri & $11.80 \mathrm{aB}$ & $16.80 \mathrm{aA}$ & $13.07 \mathrm{aB}$ & 13.89 \\
IAC-Diplomata & $12.80 \mathrm{aA}$ & $9.00 \mathrm{bB}$ & $10.80 \mathrm{aAB}$ & 10.86 \\
Safira & $11.75 \mathrm{aA}$ & $13.80 \mathrm{aA}$ & $12.20 \mathrm{aA}$ & 12.58 \\
BRS-Esplendor & $12.60 \mathrm{aA}$ & $15.53 \mathrm{aA}$ & $13.47 \mathrm{aA}$ & 13.86 \\
\hline Mean & 12.69 & 13.03 & 11.17 & \\
\hline
\end{tabular}

Means followed by the same lower case letter in the column do not differ by the Scott - Knott test and a capitalized letter on the line by Tukey test, both at $5 \%$ probability. $\mathrm{VC}=17.28 \%$ and $\mathrm{F}$ test $=4.487 * *$ 
In the crop of 2011 there was the formation of two groups. The first consisted of five genotypes (IPR-Colibri, BRS-Esplendor, CNFC-10406, IACUna and Safira) with averages ranging from 13.80 to 16.80 pods per plant and the second of three genotypes (Princesa, IAC-Diplomata and IACCentauro) with values ranging from 8.60 to 11.53 pods per plant. In 2012, there was the formation of two groups, the first of which was composed of seven genotypes which obtained number of pods per plant greater than or equal to 10.40 , and the second consisting of a single genotype that was the IACCentauro with 6.47 pods per plant.

Among the genotypes, five (IAC-Centauro, Princesa, CNFC-10406, IPR-Colibri, IACDiplomata) showed significant differences for the trait of number of pods per plant over the three years of cultivation. The IAC-Una, Safira and BRSEsplendor genotypes stood out because always compose the best statistical group and proved to be stable over the years of cultivation, which is highly desired, because even with the climatic differences retained their genetic pattern.

The observed values for the number of pods per plant considering all the years of cultivation ranged from 6.47 to 16.80 . This variation is inferior to than found by Farinelli and Lemos (2010) who obtained averages ranging from 7.6 to 23.2 pods per plant in the study of genotypes behavior grown in three cropping seasons, and by Lemos et al. (2004) who found a variation from 9.3 to 28 pods per plant in an evaluation of the bean commercial genotypes Carioca group.

Regarding the number of seeds per pod (Table 5), in 2010, two statistical groups were formed, and the first was composed of genotypes IAC-Centauro, IAC-Diplomata, BRS-Esplendor, Safira, Princesa and IPR-Colibri, which obtained values ranging from 4.47 to 5.25 grains per pod. The second group was composed of genotypes IAC-Una e CNFC-10406 with 3.42 and 3.62 grains per pod, respectively. In 2011, the behavior was opposite to that observed in 2010, because only two genotypes joined the group of large number of grains per pod, namely IAC-Diplomata and BRS-Esplendor with 5.29 and 4.94 seeds per pod, respectively. For the year 2012 genotypes showed similar behavior, with the formation of a single statistical group.

Table 5. Number of grains per pod means of eight genotypes of common bean grown in the southern state of Tocantins, in the offseason of 2010, 2011 and 2012

\begin{tabular}{lcccc}
\hline \multirow{2}{*}{ Genotypes } & \multicolumn{4}{c}{ Number of grains per pod } \\
\cline { 2 - 5 } & Offseason 2010 & Offseason 2011 & Offseason 2012 & Means \\
\hline IAC-Una & $3.42 \mathrm{bA}$ & $4.50 \mathrm{bA}$ & $3.67 \mathrm{aA}$ & 3.86 \\
IAC-Centauro & $5.25 \mathrm{aA}$ & $3.97 \mathrm{bB}$ & $3.75 \mathrm{aB}$ & 4.32 \\
Princesa & $4.65 \mathrm{aA}$ & $3.81 \mathrm{bAB}$ & $2.92 \mathrm{aB}$ & 3.79 \\
CNFC-10406 & $3.62 \mathrm{bA}$ & $4.22 \mathrm{bA}$ & $3.79 \mathrm{aA}$ & 3.88 \\
IPR-Colibri & $4.47 \mathrm{aA}$ & $4.04 \mathrm{bAB}$ & $3.30 \mathrm{aB}$ & 3.94 \\
IAC-Diplomata & $5.00 \mathrm{aA}$ & $5.29 \mathrm{aA}$ & $3.79 \mathrm{aB}$ & 4.69 \\
Safira & $4.65 \mathrm{aA}$ & $3.92 \mathrm{bA}$ & $4.32 \mathrm{aA}$ & 4.30 \\
BRS-Esplendor & $4.70 \mathrm{aA}$ & $4.94 \mathrm{aA}$ & $4.22 \mathrm{aA}$ & 4.62 \\
\hline Means & 4.47 & 4.34 & 3.72 & \\
\hline
\end{tabular}

Means followed by the same lowercase letter in the column do not differ by the Scott - Knott test and capitalized letter on the line by Tukey test, both at $5 \%$ probability. $\mathrm{VC}=15.96 \%$ and $\mathrm{F}$ test $=2.286 *$

Only IAC-Diplomata and BRS-Esplendor genotypes integrated the statistical group of highest means in all years, and BRS-Esplendor been the only one to exhibit the same behavior for the number of pods per plant characteristic, reflecting the positive correlation $(\mathrm{r}=0.17 *)$ between the number of pods and number of seeds per pod.

Regarding the behavior in the three years, it was observed that IAC-Centauro, Princesa, IPRColibri and IAC-Diplomata presented significant differences between years, especially for the first year of cultivation (2010), in which were obtained the highest average of grains per pod. This behavior is not desired in plant breeding, since these genotypes showed no increases in the number of grains per pod and neither were stable for this trait over the years grown. In the other hand, IAC-Una, CNFC-10406, Safira and BRS-Esplendor genotypes were stable regarding the number of grains per pod, corroborating Farinelli and Lemos (2010), who observed this behavior in most of the genotypes for the same trait over three harvests.

The IAC-Una, Safira and BRS-Esplendor genotypes showed stable behavior for both the characteristics number of pods per plant and for number of grains per pod. However, was observed 
that the IAC-Una and Safira despite stable as the number of grains per pod did not always comprise the largest group means, which is not ideal and desired in plant breeding, which seeks stable and high average yield components genotypes.

Considering all genotypes over the three years of cultivation, it was observed variation of 2.92 for Princesa in the year 2012 to 5.29 grains per pod for IAC-Diplomata in 2011 (Table 5). Farinelli and Lemos (2010) found similar variation amplitudes found on this study. Lemos et al. (2004) observed greater range in the number of seeds per pod.

For the mass of one hundred grains (Table 6 ) in 2010, there was the formation of three statistical groups, having IAC-Centauro as the only genotype to join the group of largest mass $30.63 \mathrm{~g}$. The group of smaller masses was composed by the Safira and BRS-Esplendor genotypes, which had masses of a hundred grains of 17.19 and $19.63 \mathrm{~g}$, respectively.

Table 6. Mass of one hundred grains means of eight common bean genotypes grown in the southern state of Tocantins, in the offseason of 2010, 2011 and 2012.

\begin{tabular}{lcccc}
\hline \multirow{2}{*}{ Genotypes } & \multicolumn{4}{c}{ Mass of one hundred grains $(\mathrm{g})$} \\
\cline { 2 - 5 } & Offseason 2010 & Offseason 2011 & Offseason 2012 & Means \\
\hline IAC-Una & $24.38 \mathrm{bB}$ & $31.64 \mathrm{aA}$ & $29.66 \mathrm{bA}$ & 28.56 \\
IAC-Centauro & $30.63 \mathrm{aAB}$ & $33.73 \mathrm{aA}$ & $26.46 \mathrm{cB}$ & 30.27 \\
Princesa & $22.78 \mathrm{bB}$ & $27.23 \mathrm{aB}$ & $35.34 \mathrm{aA}$ & 28.45 \\
CNFC-10406 & $25.92 \mathrm{bA}$ & $30.01 \mathrm{aA}$ & $29.80 \mathrm{bA}$ & 28.58 \\
IPR-Colibri & $26.42 \mathrm{bB}$ & $31.01 \mathrm{aA}$ & $26.12 \mathrm{cB}$ & 27.85 \\
IAC-Diplomata & $24.92 \mathrm{bB}$ & $31.23 \mathrm{aA}$ & $27.34 \mathrm{cAB}$ & 27.83 \\
Safira & $17.19 \mathrm{cB}$ & $21.02 \mathrm{bAB}$ & $23.49 \mathrm{dA}$ & 20.57 \\
BRS-Esplendor & $19.63 \mathrm{cA}$ & $22.32 \mathrm{bA}$ & $20.26 \mathrm{dA}$ & 20.74 \\
\hline Means & 23.98 & 28.52 & 27.31 &
\end{tabular}

Means followed by the same lowercase letter in the column do not differ by the Scott - Knott test and capitalized letter on the line by Tukey test, both at $5 \%$ probability. $\mathrm{VC}=10.12 \%$ and $\mathrm{F}$ test $=4.635 * *$

In 2011 two groups were formed, one consisting of six genotypes (Princesa, CNFC-10406, IPR-Colibri, IAC-Diplomata, IAC-Una and IACCentauro) with masses ranging from 27.23 to 33.73 $\mathrm{g}$ and another composed by two genotypes (Safira and BRS-Esplendor) with masses of 21.02 and $22.32 \mathrm{~g}$, respectively. In 2012 four groups were formed, highlighting the genotype Princesa with a mass of $35.34 \mathrm{~g}$.

Comparing the three planting years, six genotypes (IAC-Una, IAC-Centauro, Princesa, IPRColibri, IAC-Diplomata and Safira) differed significantly between the off-seasons, being observed an unstable behavior of those genotypes for this trait (Table 6). That result is not interesting in breeding programs for the common bean, where it prioritizes the selection of genotypes with stable yield components behavior, which in this case was achieved only by genotypes CNFC-10406 and BRS - Esplendor.

Contrary to what happened to characteristics such as number of pods per plant and number of seeds per pod, weight of hundred grains, only the genotype BRS-Esplendor remained having stable behavior over the years of cultivation.

The masses of a hundred grains found in this study ranged from $17.19 \mathrm{~g}$ for genotype Safira in year 2010 to $35.34 \mathrm{~g}$ for the cultivar Princesa in 2012. Ramos Junior et al. (2005) in cultivation in the rainy season and Farinelli and Lemos (2010) on crops in the rainy and dry seasons obtained lower amplitude, not having exceeded $33 \mathrm{~g}$ on their averages. Salgado et al. (2011) at a lower nitrogen amendment than the one performed on present work $\left(80 \mathrm{~kg} \mathrm{ha}^{-1}\right)$ also reported a lower amplitude in the variation of the masses of a hundred grains.

For grain yield (Table 7), in 2010 it was found the formation of three statistical groups, and the most productive group was composed only by genotype Princesa with a yield of $3133 \mathrm{~kg} \mathrm{ha}^{-1}$. The intermediate group was composed of three genotypes (IAC-Centauro, IPR-Colibri and IACDiplomata) which obtained productions between 2253.69 and $2562.91 \mathrm{~kg} \mathrm{ha}^{-1}$. The least productive group consisted of four genotypes, with grain yields ranging from 1348.01 to $1859.17 \mathrm{~kg} \mathrm{ha}^{-1}$.

In 2011 genotypes were also classified into three groups, with the most productive composed by the cultivars IAC-Una $\left(4322.13 \mathrm{~kg} \mathrm{ha}^{-1}\right)$, and the second consisting of the genotypes IAC-Centauro, Princesa, CNFC-10406 and Safira with yields ranging from 2637.45 to $3027.37 \mathrm{~kg} \mathrm{ha}^{-1}$ (Table 7). The Princesa genotype did not show the same performance at the previous year, but still included 
the second most productive group with a yield of $3027.37 \mathrm{~kg} \mathrm{ha}^{-1}$. In 2011, all genotypes exceeded yields of $2200 \mathrm{~kg} \mathrm{ha}^{-1}$, except genotype BRSEsplendor (1884.13 $\mathrm{kg} \mathrm{ha}^{-1}$ ). In 2012, there was the formation of two statistical groups, being the most productive genotypes composed of the IAC-Una,
IAC-Centauro, CNFC-10406 and IPR-Colibri, with yields ranging from 1396.56 to $2088.26 \mathrm{~kg} \mathrm{ha}^{-1}$. The second group, comprising the genotypes Princesa, IAC-Diplomata, Safira and BRS-Esplendor obtained averages of 660.79 to $1084.71 \mathrm{~kg} \mathrm{ha}^{-1}$.

Table 7. Grain yield means of eight common bean genotypes grown in the southern state of Tocantins, in the offseason of 2010, 2011 and 2012.

\begin{tabular}{lcccc}
\hline \multirow{2}{*}{ Genotypes } & \multicolumn{5}{c}{ Grain yield $\left(\mathrm{kg} \mathrm{ha}^{-1}\right)$} \\
\cline { 2 - 5 } & Offseason 2010 & Offseason 2011 & Offseason 2012 & Means \\
\hline IAC-Una & $1859.17 \mathrm{cB}$ & $4322.13 \mathrm{aA}$ & $1965.22 \mathrm{aB}$ & 2715.51 \\
IAC-Centauro & $2562.91 \mathrm{bA}$ & $2999.04 \mathrm{bA}$ & $674.90 \mathrm{bB}$ & 2319.51 \\
Princesa & $3133.44 \mathrm{aA}$ & $3027.37 \mathrm{bA}$ & $2088.26 \mathrm{aB}$ & 2247.26 \\
CNFC-10406 & $1737.23 \mathrm{cB}$ & $2916.28 \mathrm{bA}$ & $1612.57 \mathrm{aA}$ & 2037.64 \\
IPR-Colibri & $2253.69 \mathrm{bA}$ & $2246.67 \mathrm{cA}$ & $660.79 \mathrm{bB}$ & 1811.92 \\
IAC-Diplomata & $2284.53 \mathrm{bA}$ & $2490.43 \mathrm{cA}$ & $972.18 \mathrm{bB}$ & 1652.54 \\
Safira & $1348.01 \mathrm{cB}$ & $2637.45 \mathrm{bA}$ & $1084.71 \mathrm{bA}$ & 1463.86 \\
BRS-Esplendor & $1422.75 \mathrm{cA}$ & $1884.13 \mathrm{cA}$ & 1306.90 & \\
\hline Means & 2075.22 & 2815.43 & & \\
\hline
\end{tabular}

Means followed by the same lowercase letter in the column do not differ by the Scott - Knott test and capitalized letter on the line by Tukey test, both at $5 \%$ probability. $\mathrm{VC}=23.13 \%$ and $\mathrm{F}$ test $=6.094 * *$

Regarding behavior between the years of cultivation, only the genotypes BRS-Esplendor and IPR-Colibri showed no significant differences between years. That result confirms the stable behavior of the genotype BRS-Esplendor throughout the cultivation period, since this behavior was already present for all production primary components. This information is of fundamental importance for the present study, were it is seek genotypes that are adapted and stable over several years of cultivation.

Among the years, 2011 resulted in higher average productivity, whereas the lowest yield was obtained from the 2012 crop. The explanation for the lower yields found in 2012 is probably due to phytotoxicity occurred in plants caused by herbicide application at the beginning of cultivation (phenological stage V2).

Although the same product was used in the year of 2011, due to high infestation that existed in the area of cultivation, the application had to be made before it is recommended that is the $\mathrm{V} 3$ phase (RODRIGUES; ALMEIDA, 2005), that may have favored the appearance of phytotoxicity and consequently reduced productivity that year.

Thus, as for the mass of a hundred grains, instability was also observed in the yield, with decreases in productivity from the second to the third year of cultivation.

The IAC-Una was the genotype that obtained the highest productivity, exceeding 4000 $\mathrm{kg} \mathrm{ha}^{-1}$ of grains in 2011, and this performance reflected a significant positive correlation with number of pods per plant $\left(\mathrm{r}=0.24^{* *}\right)$, number of seeds per pod $\left(\mathrm{r}=0.30^{* *}\right)$ and weight of hundred grains $\left(r=0.27^{* *}\right)$. The Princesa genotype was the second to present the greatest grain yields, reaching in the years of 2010 and 2011 yields superiors than $3000 \mathrm{~kg} \mathrm{ha}^{-1}$, but in 2012 had a $78 \%$ decrease in productivity over the highest mean that was obtained in 2010.

A similar phenomenon occurred with the IAC-Diplomata that even demonstrating seemingly behavior in the first two years of cultivation with grain yields superiors to $2000 \mathrm{~kg} \mathrm{ha}^{-1}$, showed a yield decrease of $26 \%$ from 2011 to 2012. This reduction in productivity may have been influenced by the phytotoxic effect caused by the herbicide.

In the other hand the genotype BRS Esplendor, although figured among the highest means for number of pods per plant and number of seeds per pod did not obtain high yields, possibly due to the low mass averages of the hundred grains.

The grain yields exceeding $3000 \mathrm{~kg} \mathrm{ha}^{-1}$ obtained by genotypes IAC-Una and Princesa, are similar to those obtained by Ramos Junior et al. (2005) and are above the highest means observed by Salgado et al. (2011) and the national average (1197 $\left.\mathrm{kg} \mathrm{ha}^{-1}\right)$ and the state of Tocantins $\left(1850 \mathrm{~kg} \mathrm{ha}^{-1}\right)$ for the third season 2012/2013 (CONAB, 2013).

Analyzing the genotypes means in relation with the three years of cultivation it is observed that, most had yield means scores greater than $2000 \mathrm{~kg}$ $\mathrm{ha}^{-1}$ (Table 7). Those results are similar to the 
average productivity of major bean producing regions of Brazil as the Midwest $\left(2656 \mathrm{~kg} \mathrm{ha}^{-1}\right)$ and south $\left(2544 \mathrm{~kg} \mathrm{ha}^{-1}\right)$ regions, considering the third harvest crops for the year 2012/2013 (CONAB, 2013). Thus can be confirmed the enormous potential of these genotypes for common bean cultivation in the off-seasons in the state of Tocantins, with genotypes grain yields that may exceed $4000 \mathrm{~kg} \mathrm{ha}^{-1}$.

\section{CONCLUSIONS}

The Princesa genotype stood out since achieved higher productivity, higher than $3000 \mathrm{~kg}$ $\mathrm{ha}^{-1}$ in more than one cropping year, showing potential for the offseason cropping systems in the State of Tocantins.

The genotype BRS-Esplendor was the only genotype that showed stable behavior for all traits.

RESUMO: Originário das Américas o feijão comum tem apresentado enorme importância socioeconômica como principal fonte de alimento em diversos países. Devido à adoção de tecnologias como a irrigação, o feijoeiro tem sido cultivado em diferentes épocas ao longo do ano, porém, a falta de cultivares adaptadas as condições edafoclimáticas do Cerrado do Tocantins tem limitado a obtenção de melhores produtividades na época da entressafra. Desta forma, objetivou-se com este trabalho avaliar o desempenho produtivo de genótipos de feijão comum em três anos de cultivo em solo de Cerrado. Os experimentos foram conduzidos em campo na Estação Experimental da Universidade Federal do Tocantins nas entressafras dos anos 2010, 2011 e 2012. O delineamento utilizado foi o de blocos ao acaso com quatro repetições, num esquema fatorial $8 \times 3$, constituído por oito genótipos e três anos. As características avaliadas foram altura de plantas, altura de inserção da primeira vagem, número de vagens por planta, número de grãos por vagem, massa de cem grãos e produtividade de grãos. O genótipo Princesa se destacou por apresentar produtividades acima de $3.000 \mathrm{~kg} \mathrm{ha}{ }^{-1} \mathrm{em}$ mais de um ano de cultivo, demonstrando desta forma potencial para o cultivo na entressafra no Estado do Tocantins. $\mathrm{O}$ genótipo BRS-Esplendor foi o único genótipo que demonstrou comportamento estável para todas as características avaliadas.

PALAVRAS-CHAVE: Phaseolus vulgaris. Entressafra. Produtividade. Segurança alimentar.

\section{REFERENCES}

BDMEP. Banco de Dados Meteorólogicos para Ensino e Pesquisa. Banco de dados. 2012 Disponível em: <http://www.inmet.gov.br/projetos/rede/pesquisa/>. Acesso em: 10 de março de 2012.

CABRAL, P. D. S.; SOARES, T. C. B.; LIMA, A. B. P.; SOARES, Y. J. B.; SILVA, J. A. Análise de trilha do rendimento de grãos de feijoeiro (Phaseolus vulgaris L.) e seus componentes. Revista Ciência Agronômica, Fortaleza, v. 42, n. 1, p. 132-138, jan. - mar. 2011. http://dx.doi.org/10.1590/S1806-66902011000100017

CANCELLIER, E. L.; BARROS, H. B.; KISCHEL, E.; GONZAGA, L. A. M.; BRANDÃO, D. R.; FIDELIS, R. R. Eficiência agrônomica no uso de nitrogênio mineral por cultivares de arroz de terras altas. Revista Brasileira de Ciências Agrárias, Recife, v. 6, n. 4, p. 650-656, out. - dez. 2011 b. http://dx.doi.org/10.5039/agraria.v6i4a1420

CANCELLIER, L. L.; AFFÉRRI, F. S.; DOTTO, M. A.; CARVALHO, E. V.; DUTRA, D. P.; CORNÉLIO, G. L. Avaliação de top crosses de milho no sul do Tocantins. Revista Brasileira de Ciências Agrárias, Recife, v. 6, n. 4, p. 557-564, out. - dez. 2011a. http://dx.doi.org/10.5039/agraria.v6i4a865

CANCELLIER, L. L.; AFFÉRRI, F. S.; PELUZIO, J. M.; DOTTO, M. A.; LEÃO, F. F.; SANTOS, V. M. Correlação dos parâmetros da adaptabilidade e estabilidade para genótipos comerciais de milho avaliados no Tocantins. Revista Brasileira de Ciências Agrárias, Recife, v. 7, n. 2, p. 196-203, abr. - jun. 2012. http://dx.doi.org/10.5039/agraria.v7i2a933

CONAB. Companhia Nacional de Abastecimento. Acompanhamento de safra brasileira: Grãos: safra 2012/2013: Quarto levantamento. 2013. Disponível em: < www.conab.gov.br/OlalaCMS/uploads/arquivos/13_01_09_17_44_20_boletim_graos_janeiro_2013.pdf >. Acesso em: 27 de fevereiro de 2013. 
EMBRAPA. Centro Nacional de Pesquisa de Solos. Sistema Brasileiro de Classificação de Solos. 2. ed. Brasília: EMBRAPA, 2006. 306 p.

FARINELLI, R.; LEMOS, L. B. Características agronômicas de genótipos de feijoeiro cultivados nas épocas da seca e das águas. Bragantia, Campinas, v. 69, n. 2, p. 361-366, 2010. http://dx.doi.org/10.1590/S000687052010000200013

FERREIRA, D. F. Sisvar: a computer statistical analysis system. Ciência e Agrotecnologia, Lavras, v. 35, n. 6 , p. 1039-1042, nov. - dez. 2011.

FREITAS, F. O. Evidências genético-arqueológicas sobre a origem do feijão comum no Brasil. Pesquisa Agropecuária Brasileira, Brasília, v. 41, n. 7, p. 1199-1203, jul. 2006. http://dx.doi.org/10.1590/S0100204X2006000700018

LEMOS, L. B.; OLIVERIRA, R. S.; PALOMINO, E. C.; SILVA, T. R. B. Características agronômicas e tecnológicas de genótipos de feijão do grupo comercial Carioca. Pesquisa Agropecuária Brasileira, Brasília, v. 39, n. 4, p. 319-326, abr. 2004. http://dx.doi.org/10.1590/S0100-204X2004000400004

LOPES, A. S.; OLIVEIRA, G. Q.; SOUTO FILHO, S. N.; GOES, R. J.; CAMACHO, M. A. Manejo de irrigação e nitrogênio no feijoeiro comum cultivado em sistema plantio direto. Revista Ciência Agronômica, Fortaleza, v. 42, n. 1, p. 51-56, jan. - mar. 2011. http://dx.doi.org/10.1590/S1806-66902011000100007

MELO, L. C.; MELO, P. G. S.; FARIA, L. C.; DIAZ, J. L. C.; PELOSO, M. J. D.; RAVA, C. A.; COSTA, J. G. C. Interação com ambientes e estabilidade de genótipos de feijoeiro-comum na Região Centro-Sul do Brasil. Pesquisa Agropecuária Brasileira, Brasília, v. 42, n. 5, p. 715-723, mai. 2007.

OLIVEIRA, R. L.; MUNIZ, J. A.; ANDRADE, M. J. B.; REIS, R. L. Precisão experimental em ensaios com a cultura do feijão. Ciência e Agrotecnologia, Lavras, v. 33, n. 1, p. 113-119, jan. - fev. 2009.

PELÚZIO, J. M.; FIDELIS, R. R.; GIONGO, P.; SILVA, J. C.; CAPPELLARI, D.; BARROS, H. B. Adaptabilidade e estabilidade de cultivares de soja em quatro épocas de semeadura no sul do Estado do Tocantins. Revista Ceres, Viçosa, v. 55, n. 1, p. 34-40, jan. - fev. 2008.

PELUZIO, J. M.; MONTEIRO, F. J.; BARBOSA, V. S.; LOPES, L. A.; AFFÉRRI, F. S.; MELO, A. V.; FIDELIS, R. R. Desempenho de cultivares de soja na região centro-sul do estado do tocantins - safra 2007/08. Bioscience Journal, Uberlândia, v. 26, n. 5, p. 675-682, sept. - oct. 2010.

PEREIRA, H. S.; MELO, L. C.; FARIA, L. C.; PELOSO, M. J. D.; COSTA, J. G. C.; RAVA, C. A.; WENDLAND, A. Adaptabilidade e estabilidade de genótipos de feijoeiro-comum com grãos tipo carioca na Região Central do Brasil. Pesquisa Agropecuária Brasileira, Brasília, v. 44, n. 1, p. 29-37, jan. 2009. http://dx.doi.org/10.1590/S0100-204X2009000100005

PIRES, L. P. M.; PELUZIO, J. M.; CANCELLIER, L. L.; RIBEIRO, G. R.; COLOMBO, G. A.; AFFÉRRI, F. S. Desempenho de genótipos de soja, cultivados na região centro-sul do estado do Tocantins, safra 2009/2010. Bioscience Journal, Uberlândia, v. 28, n. 2, p. 214-223, mar. - apr. 2012.

RAMOS JUNIOR, E. U.; LEMOS, L. B.; SILVA, T. R. B. Componentes da produção, produtividadede grãos e características tecnológicas de cultivares de feijão. Bragantia, Campinas, v. 64, n. 1, p. 75-82, 2005. http://dx.doi.org/10.1590/S0006-87052005000100008

RODRIGUES, B. N.; ALMEIDA, F. S. Guia de herbicidas. 5. ed. Londrina: Grafmarke, 2005. 591p. 
SALGADO, F. H. M.; FIDELIS, R. R.; CARVALHO, G. L.; SANTOS, G. R.; CANCELLIER, E. L.; SILVA, G. F. Comportamento de genótipos de feijão, no período da entressafra, no sul do estado de Tocantins.

Bioscience Journal, Uberlândia, v. 27, n. 1, p. 52-58, jan. - feb. 2011.

SANTI, A. L.; DUTRA, L. M. C.; MARTIM, T. N.; BONADIMAN, R.; BELLÉ, G. L.; FLORA, L. P. D.; JAUER, A. Adubação nitrogenada na cultura do feijoeiro em plantio convencional. Ciência Rural, Santa Maria, v. 36, n. 4, p. 1079-1085, jul. - ago. 2006.

ZUCARELI, C.; PRANDO, A. M.; RAMOS JUNIOR, E. U.; NAKAGAWA, J. Fósforo na produtividade e qualidade de sementes de feijão Carioca Precoce cultivado no período das águas. Revista Ciência Agronômica, Fortaleza, v. 42, n. 1, p. 32-38, jan. - mar. 2011. http://dx.doi.org/10.1590/S180666902011000100005

ZUCARELI, C.; RAMOS JUNIOR, E. U.; BARREIRO, A. P.; NAKAGAWA, J.; CAVARIANI, C. Adubação fosfatada, componentes de produção, produtividade e qualidade fisiológica em sementes de feijão. Revista Brasileira de Sementes, Pelotas, v. 28, n. 1, p. 09-15, apr. 2006. 